\title{
Anti-human platelet antigen (HPA)-1a antibodies may affect trophoblast functions crucial for placental development: a laboratory study using an in vitro model
}

Mariana Eksteen', Gøril Heide', Heidi Tiller ${ }^{1,2}$, Yan Zhou³, Nora Hersoug Nedberg ${ }^{1,4}$, Inigo Martinez-Zubiaurre ${ }^{5}$, Anne Husebekk', Bjørn R. Skogen ${ }^{1,6}$, Tor B. Stuge ${ }^{1}$ and Mette Kjær ${ }^{1,6^{*}}$

\begin{abstract}
Background: Fetal and neonatal alloimmune thrombocytopenia (FNAIT) is a bleeding disorder caused by maternal antibodies against paternal human platelet antigens (HPAs) on fetal platelets. Antibodies against HPA-1a are accountable for the majority of FNAIT cases. We have previously shown that high levels of maternal anti-HPA-1a antibodies are associated with clinically significant reduced birth weight in newborn boys. Chronic inflammatory placental lesions are associated with increased risk of reduced birth weight and have previously been reported in connection with FNAIT pregnancies. The HPA-1a epitope is located on integrin $\beta 3$ that is associated with integrin allb (the fibrinogen receptor) on platelets and megakaryocytes. Integrin $\beta 3$ is also associated with integrin aV forming the aV $\beta 3$ integrin heterodimer, the vitronectin receptor, which is expressed on various cell types, including trophoblast cells. It is therefore thinkable that maternal anti-HPA-1a antibodies present during early pregnancy may affect placenta function through binding to the HPA-1a antigen epitope on invasive throphoblasts. The aim of the study was to examine whether interaction of a human anti-HPA-1a monoclonal antibody (mAb) with HPA-1a on trophoblast cells affect adhesion, migration and invasion of extravillous trophoblast cells.
\end{abstract}

Methods: An in vitro model with human anti-HPA-1a mAb, clone 26.4, and the first trimester extravillous trophoblast cell line HTR8/SVneo was employed. The xCELLigence system was utilized to assess the possible effect of anti-HPA-1a mAb on adhesion and migration of HTR8/SVneo cells. Specially designed chambers precoated with Matrigel were used to assess the effect on the invasive capacity of cells.

Results: We found that human anti-HPA-1a mAb 26.4 partially inhibits adhesion and migratory capacity of HTR8/SVneo cells.

Conclusions: Our findings suggest that anti-HPA-1a antibodies may affect trophoblast functions crucial for normal placental development. Future studies including primary throphoblast cells and polyclonal anti-HPA-1a antibodies are needed to confirm these results.

Keywords: Alloimmunization, HPA-1a, Anti-HPA-1a antibodies, Trophoblast cells, Placental development, aV $\beta 3$, Vitronectin receptor, Fetal and neonatal alloimmune thrombocytopenia

\footnotetext{
* Correspondence: mette.kjaer@finnmarkssykehuset.no

'Immunology research group, Department of Medical Biology, Faculty of

Health Sciences, UiT - The Arctic University of Norway, Tromsø, Norway

${ }^{6}$ Department of Laboratory Medicine, University Hospital of North Norway,

Tromsø, Norway

Full list of author information is available at the end of the article
} 


\section{Background}

Fetal and neonatal alloimmune thrombocytopenia (FNAIT) is caused by maternal antibodies against alloantigens on fetal platelets. It is a rare, but potentially life threatening disorder with intracranial hemorrhage (ICH) as the most severe complication. Severe gastrointestinal and pulmonary hemorrhages have also been reported [1]. Antibodies against human platelet antigen (HPA)-1a are accountable for nearly $85 \%$ of FNAIT cases [2]. The frequency of FNAIT due to anti-HPA-1a antibodies is around one per 1100 live births [2, 3]. We have previously found that high levels of maternal anti-HPA-1a antibodies are associated with clinically significant reduced birth weight in newborn boys [4]. A similar observation was made in an international multicenter study of FNAIT-associated ICH, showing that $23 \%$ of neonates with $\mathrm{ICH}$ were small for gestational age [5]. Chronic inflammatory placental lesions like chronic villitis and intervillositis have been reported in association with FNAIT cases [6] and such placental lesions are known to be associated with increased risk of fetal growth restriction.

Integrin $\beta 3$, carrying the HPA-1 antigen epitope, is expressed on platelets and megakaryocytes as part of $\alpha I I b \beta 3$ integrin heterodimer, the fibrinogen receptor. Integrin $\beta 3$ is also associated with $\alpha \mathrm{V}$ integrin forming integrin heterodimer $\alpha \mathrm{V} \beta 3$, also known as vitronectin receptor. The vitronectin receptor is expressed on various cell types, including trophoblast cells [7-9].

During early pregnancy, a population of trophoblast cells differentiates into highly invasive extravillous trophoblasts (EVT). EVT invade the decidualized endometrium reaching the inner third of the myometrium, and migrate along the spiral arteries remodeling them into large diameter low resistance vessels [10]. EVT migration and invasion into the uterus continues until mid-gestation and is regulated by various factors of both maternal and embryonic origin [11]. Impaired trophoblast invasion and insufficient remodeling of placental spiral arteries are common histopathological findings in placentas from pregnancies complicated by preeclampsia and low birth weight $[12,13]$.

During migration and invasion, EVT cells undergo integrin switch and upregulate expression of adhesion molecules on cell surface, including the $\alpha \mathrm{V} \beta 3[8,14]$. The important role of $\alpha \mathrm{V} \beta 3$ in mediating migration and invasion of primary cytotrophoblasts (CTB) was demonstrated in vitro $[8,15]$. It has therefore been speculated that anti-HPA-1a antibodies may affect placental development [4]. Anti-HPA-1a antibodies can bind HPA-1a on $\alpha \mathrm{V} \beta 3$ expressed on trophoblast cells $[9,16]$, and we hypothesize that this binding may affect EVT invasion, spiral artery remodeling, and in turn lead to reduced placental function.
The objective of this study was to test whether antiHPA-1a antibodies affect adhesion, migration and invasive capacity of EVT cells. For functional experiments we used an experimental in vitro model with human recombinant anti-HPA-1a monoclonal antibody (mAb), clone 26.4 [16], and a first trimester human EVT-derived cell line, HTR8/SVneo [17].

\section{Methods}

\section{Cell culture}

Human first trimester extravillous trophoblast-derived cell line, HTR8/SVneo, was kindly provided by Charles Graham (Department of Anatomy and Cell Biology at Queen's University, Kingston, ON, Canada). The cell line was generated by immortalization of primary villous explant culture from first trimester human placenta (8-10 WG) with SV40 virus [17]. HTR8/SVneo is a hypotriploid cell line (3n-) [18]. Cells were cultured in RPMI-1640 (Sigma-Aldrich, St. Louis, MO), supplemented with $10 \%$ FBS (Lonza, Basel, Switzerland), 100 $\mathrm{U} / \mathrm{ml}$ penicillin, $100 \mathrm{U} / \mathrm{ml}$ streptomycin (Lonza) and maintained at $37{ }^{\circ} \mathrm{C}$, in a $5 \% \mathrm{CO}_{2}$ humidified atmosphere. The cells were grown to $70-80 \%$ confluency and passaged $24 \mathrm{~h}$ prior to experiments. The cells were detached by incubation with $2 \mathrm{mM}$ EDTA in PBS for $5 \mathrm{~min}$ at $37^{\circ} \mathrm{C}$.

\section{Antibodies}

A recently developed human recombinant anti-HPA-1a IgG1 mAb (clone 26.4) [16] was used to explore the effect on invasive trophoblast cells. Murine anti-human $\alpha \mathrm{V} \beta 3$ mAb, clone LM609 (Millipore, Billerica, MA) was used as positive control for cell functional studies. Sodium azide from LM609 sample was removed by buffer exchange with PBS using PD SpinTrap G-25 (GE Healthcare, Little Chalfont, UK). Integrin $\beta 3$ was detected using murine mAb, clone SZ21, HPA-1-reactive [19] (Dako, Glostrup, Denmark) and rabbit mAb, clone EPR2417Y (Abcam, Cambridge, UK). Alexa Fluor 488-conjugated goat anti-mouse and goat anti-human antibodies (Invitrogen, Carlsbad, CA) were used as secondary antibodies in flow cytometry experiments. Human myeloma plasma IgG1 (Sigma) and murine IgG1 (Beckman Coulter, Brea, CA) were used as isotype controls. Horseradish peroxidase (HRP)-conjugated goat anti-rabbit IgG (Thermo Scientific, Waltham, MA) was used as a detection antibody in the western blot experiment.

\section{Western blot}

Platelets from an HPA-1aa-genotyped donor $\left(16 \times 10^{8}\right.$ cells) and HTR8/SVneo cells $\left(20 \times 10^{6}\right.$ cells $)$ were lysed using $3 \mathrm{ml}$ RIPA buffer (Sigma) in the presence of protease inhibitor (cOmplete Tablets Mini EDTA-free, Roche Diagnostics, Basel, Switzerland). Twelve microliters of 
platelet lysate diluted 1:1000 and $12 \mu \mathrm{l}$ of HTR8/SVneo cell lysate were reduced and separated in a 4-12\% SDS polyacrylamide gel (Life Technologies, Carlsbad, CA). Electrophoresed samples were transferred to a PVDF membrane (Life Technologies). Nonspecific binding sites were blocked by Super blocking buffer (Thermo Scientific) containing $0.05 \%$ Tween 20 and $0.2 \%$ goat IgG (Thermo Scientific) for $1 \mathrm{~h}$. Primary and secondary antibodies were diluted in Super blocking buffer containing $0,05 \%$ Tween 20 . The PVDF membrane was incubated overnight at $4{ }^{\circ} \mathrm{C}$ with rabbit anti- $\beta 3$ antibody diluted 1:2000 (clone EPR2417Y). After a washing step, the membrane was incubated with HRP-conjugated goat anti-rabbit IgG diluted 1:1000 for $1 \mathrm{~h}$ at RT followed by a washing step with PBS $0.05 \%$ Tween 20 . The membrane was covered by $3 \mathrm{ml}$ of Supersignal West Femto Maximum Sensitivity Substrate (Thermo Scientific) and left for 5 min in the dark at RT. Integrin $\beta 3$ was visualized using the luminescent image analyzer ImageQuant LAS 4000 (GE Healthcare, Little Chalfont, UK). Integrin $\alpha$ V $\beta 3$ purified from human placenta was used as a positive control (Millipore, Billerica, MA). The expected $\beta 3$ subunit band is of approximately $90-110 \mathrm{kDa}$.

\section{Flow cytometry}

To stain cell surface membrane integrins, the HTR8/ SVneo cells were harvested, washed and re-suspended in PBS $0.2 \%$ bovine serum albumin, and incubated $10 \mathrm{~min}$ at RT with unconjugated mouse anti-human $\beta 3$ (clone SZ21) or human anti-HPA-1a (clone 26.4) mAbs. Mouse and human IgG1 were used as isotype controls. After a washing step, cells were stained with Alexa Fluor 488-conjugated goat anti-mouse and goat anti-human antibodies respectively, and analyzed by flow cytometry (Canto, Becton Dickinson, Franklin Lakes, NJ). The acquired data was analyzed using Flowjo software (TreeStar, Ashland, OR, USA).

\section{HPA-1 genotyping}

The DNA and RNA from HTR8/SVneo cells and donor samples were isolated and used for HPA-1 genotyping by TaqMan $5^{\prime}$ nuclease assay as described previously $[20,21]$.

\section{Y-chromosome DNA test}

The DNA isolated from HTR8/SVneo cells was used for Y-chromosome DNA test by TaqMan $5^{\prime}$ nuclease assay. The primers used for the assay were described previously [22] and FAM-labelled probe was designed in house.

\section{Monitoring cell adhesion and migration}

Cell adhesion and migration were monitored in real time using the xCELLigence system (Roche Applied Science,
Penzberg, Germany) [23]. For determining the rate of cell adherence, E-plate 16 assemblies were coated with human vitronectin (Promega, Madison, WI) by incubating $1 \mu \mathrm{g} / \mathrm{ml}$ solution in $100 \mu \mathrm{l}$ volume for $1 \mathrm{~h}$ at $37^{\circ} \mathrm{C}$. The wells were washed twice with PBS before $50 \mu \mathrm{l}$ complete medium was added and the background measurements recorded. The cells were seeded at 20,000 cells/well in a $40 \mu \mathrm{l}$ volume. From a solution of $200 \mu \mathrm{g}$ antibodies/ml PBS, $10 \mu \mathrm{l}$ were added to each well (human IgG1 as negative control, 26.4 and LM609). Each plate was then assembled on the RTCA DP analyzer, and data were gathered at 5 -min intervals for $7 \mathrm{~h}$ at $37{ }^{\circ} \mathrm{C}$, in a $5 \% \mathrm{CO}_{2}$ humidified atmosphere.

Cell migration was monitored using specially designed CIM-plate 16 with $8-\mu \mathrm{m}$ pores. The sensor side (bottom side) of each well of the upper chamber was coated with human vitronectin by incubating $30 \mu \mathrm{l}$ of the $1 \mu \mathrm{g} / \mathrm{ml}$ solution for $30 \mathrm{~min}$ at RT. The lower chambers were filled with medium containing 10\% FBS, used as chemoattractant. The upper chambers were filled with serumfree medium $(50 \mu \mathrm{l} /$ well $)$, and the plate was incubated at $37{ }^{\circ} \mathrm{C}$ in $5 \% \mathrm{CO}_{2}$ for $1 \mathrm{~h}$. After recording background measurements, the cells were seeded into the upper chamber at 40,000 cells in $40 \mu \mathrm{l}$ per well and $10 \mu \mathrm{l}$ of $200 \mu \mathrm{g} / \mathrm{ml}$ antibodies in PBS were added. The plate was then incubated for $30 \mathrm{~min}$ at RT, assembled on the RTCA DP analyzer and data collected every $15 \mathrm{~min}$ for $24 \mathrm{~h}$ at $37^{\circ} \mathrm{C}$, in a $5 \% \mathrm{CO}_{2}$ humidified atmosphere. The obtained data were analyzed using the RTCA 1.2 software supplied with the instrument.

\section{Invasion assay}

Cell invasion was evaluated using BD BioCoat Matrigel Invasion Chambers (BD Biosciences). The Chambers (24 well Plate 8 Micron with Control inserts) were prepared following the manufacturer's instructions. The RPMI 1640 medium with 5\% FBS was used as chemoattractant. HTR8/SVneo cells were seeded into each insert at $40,000 \mathrm{cells} /$ well in a $180 \mu \mathrm{l}$ volume in serum free medium and $20 \mu \mathrm{l}$ of $200 \mu \mathrm{g} / \mathrm{ml}$ antibodies in PBS were added (total antibody concentration of $20 \mu \mathrm{g} / \mathrm{ml}$ ). The plate was incubated for $48 \mathrm{~h}$ at $37{ }^{\circ} \mathrm{C}$, in a $5 \% \mathrm{CO}_{2} \mathrm{hu}-$ midified atmosphere. After incubation, the non-invading cells were scrubbed from the upper part of the inserts by a cotton swab.

The invaded cells were measured by the MTT (3-[4,5dimethylthiazol-2-yl]-2,5 diphenyl tetrazolium bromide) assay. The MTT (Sigma) at $5 \mathrm{mg} / \mathrm{ml}$ in RPMI 1640 medium without phenol red, was diluted 1:10 and $350 \mu \mathrm{l}$ of the dilution was added to each clean well. The inserts were transferred to MTT solution and incubated for $2 \mathrm{~h}$ at $37{ }^{\circ} \mathrm{C}$, in a $5 \% \mathrm{CO}_{2}$ humidified atmosphere. Next, the inserts were transferred into clean wells with $220 \mu \mathrm{l}$ of $0.04 \mathrm{M} \mathrm{HCl}$ in pure isopropanol and incubated for $5 \mathrm{~min}$ 
at RT. The inserts were removed and the solution transferred to centrifuge tubes and centrifuged for $2 \mathrm{~min}$ at $16,000 \mathrm{x}$ g. Of the solution, $100 \mu \mathrm{l}$ was transferred into a 96-well microtiter plate and absorption at $560 \mathrm{~nm}$ was measured by an ELISA- reader (Multiskan Ex, Thermo Scientific).

\section{Statistical Analysis}

A one-way analysis of variance (ANOVA) in SPSS software (SPSS Inc., Chicago, IL, USA) was used to analyze adhesion, migration and invasion experimental data. A $P$-value of $<0.05$ was considered significant. Sigma Plot 13 software (San Jose, CA) was used to present the data.

\section{Results}

A human anti-HPA-1a mAb 26.4 binds HPA-1a epitope on HTR8/SVneo cells

Integrin $\beta 3$ expression by HTR8/SVneo cells was assessed with Western blot and flow cytometry techniques. Both techniques demonstrated expression of integrin $\beta 3$ by HTR8/SVneo cells (Fig. 1a and b). The cells expressed $\alpha \mathrm{V}$, but were negative for $\alpha \mathrm{IIb}$ (data not shown), indicating that HTR8/SVneo cells express $\beta 3$ integrin only in association with $\alpha \mathrm{V}$ integrin. Next, HTR8/SVneo cells were genotyped HPA-1ab. Finally, flow cytometry analysis

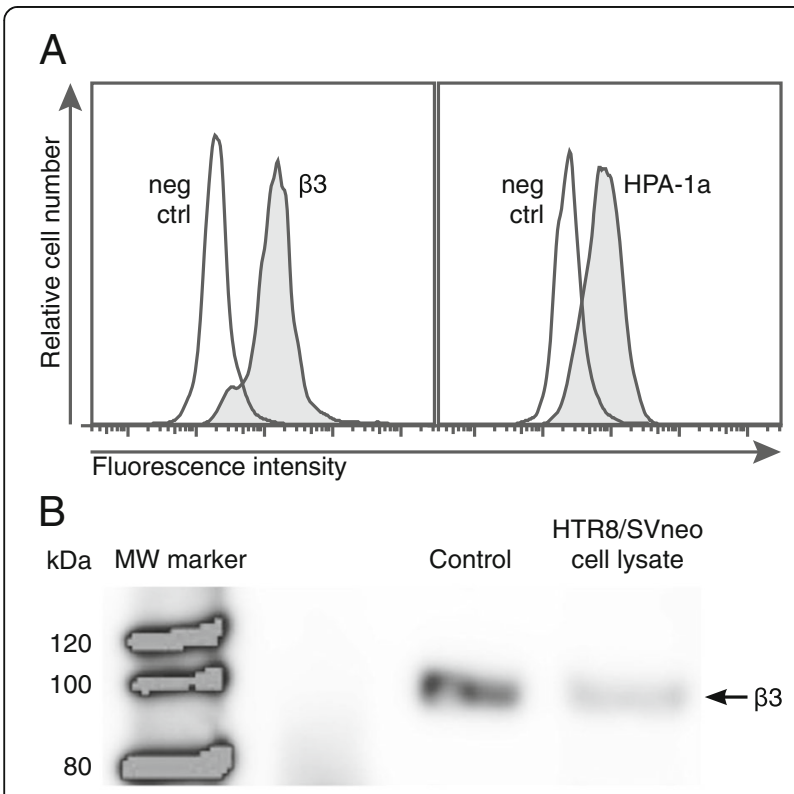

Fig. 1 Expression of integrin $\beta 3$ and HPA-1a on HTR8/SVneo cells. a Flow cytometric analysis of cells incubated with murine anti-human 33 HPA-1-reactive mAb SZ21 and human HPA-1a-specific mAb 26.4, or isotype control. b Detection of integrin $\beta 3$ in lysed HTR8/SVneo cells by Western blot. Integrin aV 33 isolated from human placenta used as control. Integrin $\beta 3$ detected as a band of about $100 \mathrm{kDa}$ in the control and cell lysate. Western blot image was spliced to rearrange the order of samples within one experiment. Dashed lines indicate where the images were joined. Figure $A$ and $B$ are representative for at least three independent experiments demonstrated that human anti-HPA-1a mAb bound to intact HTR8/SVneo cells (Fig. 1a).

\section{A human anti-HPA-1a mAb 26.4 partially inhibits adhesion and migratory capacity of HTR8/SVneo cells}

The effect of a mAb 26.4 on trophoblast cell adhesion and migration was explored using the xCELLigence system. mAb 26.4 was used at a concentration of $20 \mu \mathrm{g} / \mathrm{ml}$, which corresponds to about $400 \mathrm{IU} / \mathrm{ml}$ of anti-HPA-1a antibody activity as measured by quantitative $\mathrm{mAb}$ immobilization of platelet antigens (MAIPA) assay [24]. $\mathrm{mAb} 26.4$ significantly inhibited adhesion and migration of HTR8/SVneo cells to vitronectin-coated membranes by $15-20 \%$ (Fig. $2 \mathrm{a}$ and $\mathrm{b}$ ) and $18-23 \%$ (Fig. 2c and d), respectively. Anti- $\alpha \mathrm{V} \beta 3$ murine mAb (clone LM609) similarly inhibited adhesion and migration of HTR8/ SVneo cells (data not shown).

The effect of mAb 26.4 on invasive capacity of first trimester trophoblast cells was studied utilizing Matrigel pre-coated invasion chambers. The mAb inhibited invasive capacity of cells in three out of four independent experiments by 9,15 and $25 \%$ (Fig. 3). The inhibition was not statistically significant $(p=0.13)$. Anti- $\alpha \mathrm{V} \beta 3$ murine mAb (clone LM609) did not affect invasive capacity of HTR8/SVneo cells (data not shown).

\section{HTR8/SVneo cells originate from a female conceptus}

To identify whether HTR8/SVneo cells originate from a female or male conceptus, the Y-chromosome DNA test has been performed. HTR8/SVneo cells were tested negative for Y-chromosome DNA, indicating that the cells originate from a female conceptus.

\section{Discussion}

In the present study, we have demonstrated that a human HPA-1a-specific mAb inhibit adhesion and migratory capacity of EVT cells in an in vitro model.

To study the possible effect of anti-HPA-1a antibodies on EVT we utilized transformed first trimester EVTderived cells (HTR8/SVneo cell line), which were reported to share phenotypic and functional characteristics of EVT cells $[17,25]$. We have shown that HTR8/SVneo cells express HPA-1a epitope as part of $\alpha \mathrm{V} \beta 3$ integrin complex, and importantly, that anti-HPA-1a antibodies interact with HPA-1a on these cells. In this study, we used a human anti-HPA-1a mAb, clone26.4, generated from a $B$ cell derived from a woman HPA-1a immunized in connection with pregnancy, who had two children affected by FNAIT. mAb 26.4 was expressed recombinantly and found to be highly specific for HPA-1a, bound strongly to HPA- 1 a epitopes on $\alpha \operatorname{IIb} \beta 3$ from platelets as well as $\alpha \mathrm{V} \beta 3$ from trophoblasts [16]. Thus, the HTR8/SVneo cell line with mAb 26.4 could be a 

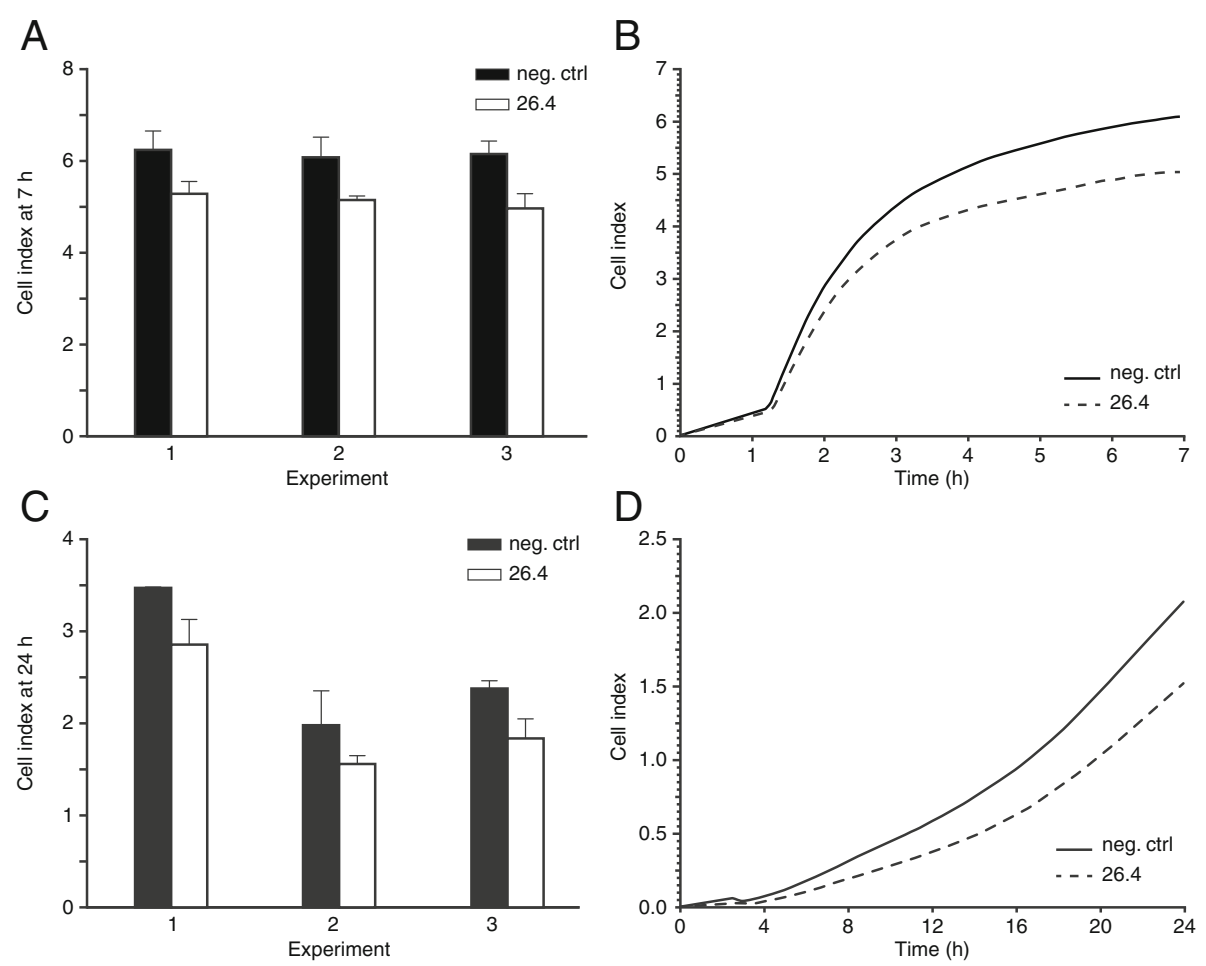

Fig. 2 Effect of anti-HPA-1a antibodies on EVT adhesion and migration. HTR8/SVneo cells were plated on E-plate 16 (for adhesion experiments) and CIM-plate 16 (for migration experiments) in the presence of mAb 26.4 or human IgG1 as a negative control. Cell adhesion was monitored using xCELLigence system over $7 \mathrm{~h}$, and cell migration over $24 \mathrm{~h}$. The samples were run in triplicates and experiments repeated three times each. Each column represent the range in cell index of one sample run in triplicate. Results presented in the graphs (distinguished by experiment due to high variations in cell index between the experiments) are from three independent experiments: a adhesion; $\mathbf{c}$ migration. Plots visualize cell spreading and attachment in real time: $\mathbf{b}$ adhesion; $\mathbf{d}$ migration. Plots are representative for three independent experiments

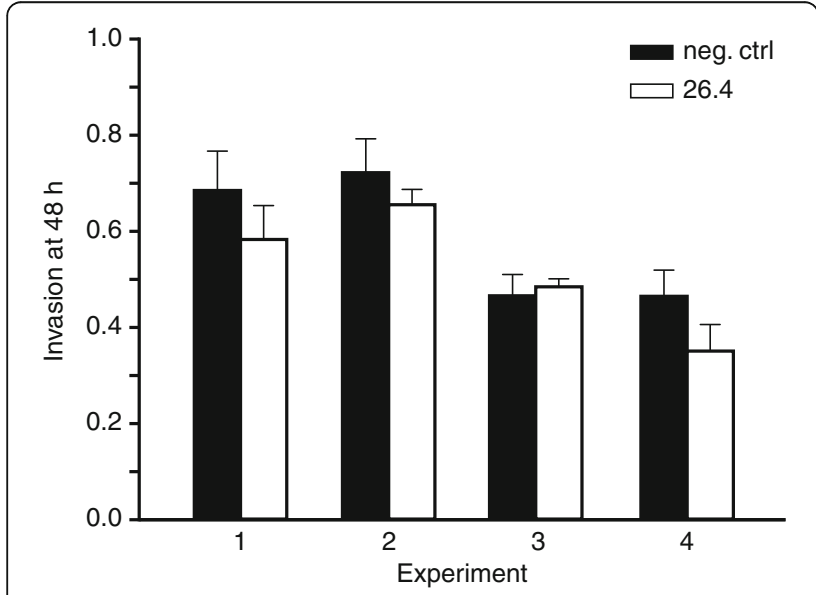

Fig. 3 Effect of anti-HPA-1a antibodies on invasive capacity of EVT. HTR8/SVneo cells were cultured in Matrigel coated chambers in the presence of mAb 26.4 or human IgG1 as a negative control for $48 \mathrm{~h}$. The samples were run in quadruplicates and experiment repeated four times. Each column represent the range in cell index of one sample run in quadruplicate. Cell invasion was evaluated by MTT-assay. The invasion data is expressed as the ratio of invasion through the Matrigel Matrix and membrane relative to the migration through the control membrane useful model to study possible effect of anti-HPA-1a antibodies on EVT.

The idea that alloantibodies reactive with fetal integrins expressed on trophoblast cells can impair placental function is not new. A histological study of placentas from FNAIT-affected pregnancies described chronic villitis in pregnancies not treated with IVIG [26]. And in a recent histopatological study, FNAIT was associated with chronic chorioamnionitis, basal chronic villitis and intervillositis [6]. In addition, a case of FNAIT associated with massive chronic intervillositis has also been described [27]. Chronic villitis and intervillositis are placental lesions known to be associated with poor fetal growth $[28,29]$. Further, an association between FNAIT due to anti-HPA-1a antibodies and increased risk of miscarriage has also been suggested, indicating that placental development may be affected in early stages of pregnancy [30,31].

Vitronectin receptor, carrying HPA-1 antigen epitope, is crucial for cell-matrix and cell-cell interactions, modulating growth, survival, motility and differentiation of angiogenic endothelial cells (EC), osteoclasts, tumor cells and other cell types [32]. Blocking $\alpha \mathrm{V} \beta 3$ was shown to disrupt the invasive and proliferative program of sprouting 
EC, and suppress angiogenesis [33-35] impede tumor progression [36], and hinder osteoclast adhesion and migration [32]. The important role of $\alpha \mathrm{V} \beta 3$ in mediating EVT cells invasion [8] and adhesion to ECs [37, 38] was shown in vitro.

Further, the capacity of anti-HPA-1a antibodies to affect $\alpha \mathrm{V} \beta 3$-expressing EC in vitro has been reported $[35,39,40]$. Anti-HPA-1a maternal sera affected spreading and monolayer integrity of human umbilical cord endothelial cells (HUVEC) [39] and inhibited HUVEC proliferation and formation of capillary-like networks [35]. The latter findings suggest that anti-HPA-1a antibodies can cause systemic vascular damage, impair angiogenesis, and subsequently can be an independent cause of FNAIT-associated ICH. Further, in a recent study, Santoso S. with co-workers have shown that only anti-HPA-1a antibodies binding selectively to the $\alpha \mathrm{V} \beta 3$ complex interfere with angiogenesis [40].

Mechanisms of inhibitory effects of anti-HPA-1a antibodies are still incompletely understood. It has been shown that anti-HPA-1a antibodies can impair angiogenic and increase proapoptotic signaling in HUVECs [35]. It has also been hypothesized that anti-HPA-1a IgG antibodies block the ligand RGD binding site on $\alpha \mathrm{V} \beta 3$ and $\alpha \operatorname{IIb} \beta 3$ by indirect competition (i.e., steric hindrance) [41].

The HPA-1a epitope is formed by only one amino acid change, L33P, in integrin $\beta 3$, and, therefore, all antiHPA-1a antibody epitopes overlap reacting with the L33 residue. Yet, anti-HPA-1a antibodies are reported to be heterogeneous in their footprint on integrin $\beta 3$ [42] and binding affinity [43-45]. In fact, recently it was found that antibodies of this specificity can be even more complex; $\alpha \mathrm{V} \beta 3-, \alpha \operatorname{IIb} \beta 3$-specific, or bind antigen independently of the complex [40]. Thus, the effect of a single mAb specific for HPA-1a, as used in this study, may not be representative for different polyclonal antibody profiles among immunized women. Still, our finding that an anti-HPA-1a mAb could affect functions of HTR8/SVneo cells is interesting, indicating that anti-HPA-1a antibodies may affect functions of extravillous trophoblast cells in vivo.

Only male neonates had significantly reduced birth weight in pregnancies with high levels of maternal antiHPA-1a antibodies in a retrospective observational study [4]. Male sex of the fetus is a well known risk factor for adverse pregnancy outcome [46]. Evidence is emerging on the influence of fetal sex on placental development and function [47]. The placenta displays sexually dismorphic differences in gene expression and responds to maternal factors in a sex-dependent manner [48]. The magnitude of the effects of anti-HPA-1a antibodies on trophoblast cells may depend on the sex of the placenta. In this study we used a cell line HTR8/SVneo which we found to originate from a female placenta. In the follow up studies, it is therefore important to compare the effects of anti-HPA-1a antibodies on trophoblast cells originating from male and female placentas.

\section{Conclusions}

We have demonstrated that a human anti-HPA-1a mAb impaired adhesion and migratory capacity of EVTderived cell line in vitro. We speculate that anti-HPA-1a antibodies may hinder placental development, and consequently, may be involved in early pregnancy loss as well as poor placental function. Further studies with primary trophoblast cells and maternal anti-HPA-1a sera, together with a histopathological study of placentas from pregnancies affected by FNAIT are important to support our finding.

\section{Abbreviations}

CTB: Cytotrophoblast; EC: Endothelial cells; EVT: Extravillous trophoblast; FNAIT: Fetal and neonatal alloimmune thrombocytopenia; HPA-1a: Human platelet antigen-1a; ICH: Intracranial hemorrhage; WG: Weeks gestation

\section{Acknowledgements}

We thank Dr. Charles Graham (Queen's University, Kingston, Ontario, Canada) for his generous gift of the HTR8/SVneo cells used in this study. We thank Mona Nystad (Department of Clinical Medicine, Women's Health and Perinatology Research Group, Faculty of Health Sciences, UiT - The Arctic University of Norway, Tromsø, Norway) for her assistance with invasion experiments.

\section{Funding}

This work was supported by the grants from the Norwegian Research Council and North Norwegian Health Authorities.

\section{Availability of data and materials \\ Please contact author for data requests.}

\section{Authors' contributions}

MK planned the overall study protocol and together with ME and GH designed and performed the experiments, analyzed data and wrote the manuscript. HT analyzed data and wrote the manuscript. YZ supervised and performed immunocytochemistry experiments (not included in the paper). $\mathrm{NHN}$ produced the recombinant version of the mAb 26.4. IM supervised the xCELLigence experiments and analyzed data. AH, BS and MK conceived the project and together with TS supervised the study. All authors contributed to analyses and interpretation of data, critically revised the manuscript and approved the final version.

\section{Competing interests}

$\mathrm{NHN}, \mathrm{AH}, \mathrm{BS}$ and MK have financial relationship with the Prophylix Pharma AS. Prophylix Parma AS did not finance or influence the study. The authors declare that they have no competing interests.

\section{Consent for publication \\ Not applicable.}

Ethics Approval and Consent to Participate Not applicable.

\section{Publisher's Note}

Springer Nature remains neutral with regard to jurisdictional claims in published maps and institutional affiliations.

\section{Author details}

${ }^{1}$ Immunology research group, Department of Medical Biology, Faculty of Health Sciences, UiT - The Arctic University of Norway, Tromsø, Norway. ${ }^{2}$ Department of Obstetrics and Gynecology, University Hospital of North Norway, Tromsø, Norway. ${ }^{3}$ Department of Obstetrics, Gynecology \& 
Reproductive Sciences, University of California, San-Francisco, CA, USA. ${ }^{4}$ Prophylix Pharma AS, Tromsø, Norway. ${ }^{5}$ Bone and Joint research group, Department of Clinical Medicine, UiT- The Arctic University of Norway, Tromsø, Norway. ${ }^{6}$ Department of Laboratory Medicine, University Hospital of North Norway, Troms $\varnothing$, Norway.

Received: 26 November 2016 Accepted: 2 April 2017

Published online: 21 April 2017

\section{References}

1. Winkelhorst D, Kamphuis MM, de Kloet LC, Zwaginga JJ, Oepkes D, Lopriore E. Severe bleeding complications other than intracranial hemorrhage in neonatal alloimmune thrombocytopenia: a case series and review of the literature. Transfusion. 2016;56:1230-5.

2. Kjeldsen-Kragh J, Killie MK, Tomter G, Golebiowska E, Randen I, Hauge R, Aune B, Øian P, Dahl LB, Pirhonen J, et al. A screening and intervention program aimed to reduce mortality and serious morbidity associated with severe neonatal alloimmune thrombocytopenia. Blood. 2007;110:833-9.

3. Williamson LM, Hackett G, Rennie J, Palmer CR, Maciver C, Hadfield R, Hughes D, Jobson S, Ouwehand WH. The Natural History of Fetomaternal Alloimmunization to the Platelet-Specific Antigen HPA-1a (PIA1, Zwa) as Determined by Antenatal Screening. Blood. 1998:92:2280-7.

4. Tiller H, Killie MK, Husebekk A, Skogen B, Ni H, Kjeldsen-Kragh J, Ølan P. Platelet antibodies and fetal growth: maternal antibodies against fetal platelet antigen 1a are strongly associated with reduced birthweight in boys. Acta Obstet Gynecol Scand. 2012;91:79-86.

5. Tiller $H$, Kamphuis MM, Flodmark O, Papadogiannakis N, David AL, Sainio S, Koskinen S, Javela K, Wikman AT, Kekomaki R, et al. Fetal intracranial haemorrhages caused by fetal and neonatal alloimmune thrombocytopenia: an observational cohort study of 43 cases from an international multicentre registry. BMJ Open. 2013;3:e002490.

6. Dubruc E, Lebreton F, Giannoli C, Rabilloud M, Huissoud C, DevouassouxShisheboran M, Allias F. Placental histological lesions in fetal and neonatal alloimmune thrombocytopenia: A retrospective cohort study of 21 cases. Placenta. 2016:48:104-9.

7. Hynes RO. Integrins: Versatility, modulation, and signaling in cell adhesion. Cell. 1992;69:11-25.

8. Zhou Y, Fisher SJ, Janatpour M, Genbacev O, Dejana E, Wheelock M, Damsky $\mathrm{CH}$. Human cytotrophoblasts adopt a vascular phenotype as they differentiate. A strategy for successful endovascular invasion? J Clin Invest. 1997;99:2139-51.

9. Vanderpuye OA, Labarrere CA, Mclntyre JA. A vitronectin-receptor-related molecule in human placental brush border membranes. Biochem J. 1991; 280(Pt 1):9-17.

10. Pijnenborg R, Bland JM, Robertson WB, Brosens I. Uteroplacental arterial changes related to interstitial trophoblast migration in early human pregnancy. Placenta. 1983:4:397-413.

11. Knöfler M, Pollheimer J. IFPA Award in Placentology Lecture: Molecular regulation of human trophoblast invasion. Placenta. 2012;33:S55-62.

12. Brodsky D, Christou H. Current Concepts in Intrauterine Growth Restriction. J Intensive Care Med. 2004;19:307-19.

13. Khong TY, De Wolf F, Robertson WB, Brosens I. Inadequate maternal vascular response to placentation in pregnancies complicated by preeclampsia and by small-for-gestational age infants. Br J Obstet Gynaecol. 1986:93:1049-59.

14. Damsky CH, Fitzgerald ML, Fisher SJ. Distribution patterns of extracellular matrix components and adhesion receptors are intricately modulated during first trimester cytotrophoblast differentiation along the invasive pathway, in vivo. J Clin Invest. 1992;89:210-22.

15. Kabir-Salmani M, Shiokawa S, Akimoto Y, Sakai K, Nagamatsu S, Sakai K, Nakamura Y, Lotfi A, Kawakami H, Iwashita M. Alphavbeta3 integrin signaling pathway is involved in insulin-like growth factor I-stimulated human extravillous trophoblast cell migration. Endocrinology. 2003;144: 1620-30.

16. Eksteen M, Tiller H, Averina M, Heide G, Kjaer M, Ghevaert C, Michaelsen TE, Ihle O, Husebekk A, Skogen B, Stuge TB. Characterization of a human platelet antigen-1a-specific monoclonal antibody derived from a B cell from a woman alloimmunized in pregnancy. J Immunol. 2015:194:5751-60.

17. Graham CH, Hawley TS, Hawley RG, MacDougall JR, Kerbel RS, Khoo N, Lala PK. Establishment and characterization of first trimester human trophoblast cells with extended lifespan. Exp Cell Res. 1993;206:204-11.
18. Weber M, Vasheghani F, Göhner C, Liehr T, Schleussner E, Fitzgerald JS, Markert UR, Weise A. Karyotypes of trophoblastic cell lines. Placenta. 2016;45:108.

19. Weiss EJ, Goldschmidt-Clermont PJ, Grigoryev D, Jin Y, Kickler TS, Bray PF. A monoclonal antibody (SZ21) specific for platelet GPIlla distinguishes P1 A1 from PI A2. Tissue Antigens. 1995;46:374-81.

20. Skogen B, Bellissimo DB, Hessner MJ, Santoso S, Aster RH, Newman PJ, McFarland JG. Rapid determination of platelet alloantigen genotypes by polymerase chain reaction using allele-specific primers. Transfusion. 1994:34:955-60.

21. Bugert $P, M c B$ ride $S$, Smith $G$, Dugrillon A, Klüter H, Ouwehand WH, Metcalfe P. Microarray-based genotyping for blood groups: comparison of gene array and 5'-nuclease assay techniques with human platelet antigen as a model. Transfusion. 2005:45:654-9.

22. Dhallan R, Au W, Mattagajasingh S, et al. MEthods to increase the percentage of free fetal dna recovered from the maternal circulation. JAMA. 2004;291:1114-9.

23. Keogh RJ. New technology for investigating trophoblast function. Placenta. 2010;31:347-50.

24. Killie MK, Salma W, Bertelsen E, Skogen B, Husebekk A. Quantitative MAIPA: Comparison of different MAIPA protocols. Transfus Apher Sci. 2010;43:149-54.

25. Kilburn BA, Wang J, Duniec-Dmuchowski ZM, Leach RE, Romero R, Armant DR. Extracellular matrix composition and hypoxia regulate the expression of HLA-G and integrins in a human trophoblast cell line. Biol Reprod. 2000;62:739-47.

26. Althaus J, Weir EG, Askin F, Kickler TS, Blakemore K. Chronic villitis in untreated neonatal alloimmune thrombocytopenia: an etiology for severe early intrauterine growth restriction and the effect of intravenous immunoglobulin therapy. Am J Obstet Gynecol. 2005;193:1100-4.

27. Tchakarov A, Coffey A, Tatevian N. Neonatal Alloimmune Thrombocytopenia Associated with Massive Chronic Intervillositis: A Case Report and Review of the Literature. Pediatr Dev Pathol. 2013;16:32-4.

28. Tamblyn JA, Lissauer DM, Powell R, Cox P, Kilby MD. The immunological basis of villitis of unknown etiology - Review. Placenta. 2013;34:846-55.

29. Boyd TK, Redline RW. Chronic histiocytic intervillositis: a placental lesion associated with recurrent reproductive loss. Hum Pathol. 2000;31:1389-96.

30. Murphy MF, Hambley H, Nicolaides K, Waters AH. Severe fetomaternal alloimmune thrombocytopenia presenting with fetal hydrocephalus. Prenat Diagn. 1996;16:1152-5.

31. Tiller $H$, Fedorcsak $P$, Skogen BR. Old tools revisited give hope - new treatment option for families with a history of severe FNAIT complications. Acta Obstet Gynecol Scand 2016:n/a-n/a.

32. Wilder $\mathrm{R}$. Integrin alpha $\mathrm{V}$ beta 3 as a target for treatment of rheumatoid arthritis and related rheumatic diseases. Ann Rheum Dis. 2002;61:ii96-9.

33. Brooks PC, Clark RA, Cheresh DA. Requirement of vascular integrin alpha v beta 3 for angiogenesis. Science. 1994;264:569-71.

34. Drake CJ, Cheresh DA, Little CD. An antagonist of integrin alpha $\vee$ beta 3 prevents maturation of blood vessels during embryonic neovascularization. J Cell Sci. 1995;108:2655-61.

35. Yougbare I, Lang S, Yang H, Chen P, Zhao X, Tai WS, Zdravic D, Vadasz B, Li C, Piran S, et al. Maternal anti-platelet beta3 integrins impair angiogenesis and cause intracranial hemorrhage. J Clin Invest. 2015;125:1545-56.

36. Sloan EK, Pouliot N, Stanley KL, Chia J, Moseley JM, Hards DK, Anderson RL. Tumor-specific expression of av $\beta 3$ integrin promotes spontaneous metastasis of breast cancer to bone. Breast Cancer Res. 2006:8:R20.

37. Thirkill TL, Douglas GC. The Vitronectin Receptor Plays a Role in the Adhesion of Human Cytotrophoblast Cells to Endothelial Cells. Endothelium. 1999;6:277-90.

38. Douglas GC, Thirkill TL, Blankenship TN. Vitronectin receptors are expressed by macaque trophoblast cells and play a role in migration and adhesion to endothelium. BBA-Mol Cell Res. 1999;1452:36-45.

39. van Gils JM, Stutterheim J, van Duijn TJ, Zwaginga JJ, Porcelijn L, de Haas $M$, Hordijk PL. HPA-1a alloantibodies reduce endothelial cell spreading and monolayer integrity. Mol Immunol. 2009;46:406-15.

40. Santoso S, Wihadmadyatami H, Bakchoul T, Werth S, Al-Fakhri N, Bein G, Kiefel V, Zhu J, Newman PJ, Bayat B, Sachs UJ. Antiendothelial avß3 Antibodies Are a Major Cause of Intracranial Bleeding in Fetal/Neonatal Alloimmune Thrombocytopenia. Arterioscler Thromb Vasc Biol. 2016;36(8):1517-24.

41. Abou-Chaker K, Meyer O, Salama A. Rapid typing of the human neutrophil antigen 1 a by the particle gel agglutination assay. Tissue Antigens. 2009;73:242-4.

42. Stafford P, Ghevaert CJG, Campbell K, Proulx C, Smith G, Williamson LM, Ranasinghe $\mathrm{E}$, Watkins NA, Huntington JA, Ouwehand WH. Immunologic and structural analysis of eight novel domain-deletion $\beta 3$ integrin 
peptides designed for detection of HPA-1 antibodies. J Thromb Haemost. 2008;6:366-75.

43. Socher I, Andrei-Selmer C, Bein G, Kroll H, Santoso S. Low-avidity HPA-1a alloantibodies in severe neonatal alloimmune thrombocytopenia are detectable with surface plasmon resonance technology. Transfusion. 2009:49:943-52.

44. Bakchoul T, Kubiak S, Krautwurst A, Roderfeld M, Siebert HC, Bein G, Sachs UJ, Santoso S. Low-avidity anti-HPA-1a alloantibodies are capable of antigen-positive platelet destruction in the NOD/SCID mouse model of alloimmune thrombocytopenia. Transfusion. 2011;51:2455-61.

45. Peterson JA, Kanack A, Nayak D, Bougie DW, McFarland JG, Curtis BR, Aster RH. Prevalence and clinical significance of low-avidity HPA-1a antibodies in women exposed to HPA-1a during pregnancy. Transfusion. 2013;53:1309-18.

46. Sheiner E, Levy A, Katz M, Hershkovitz R, Leron E, Mazor M. Gender Does Matter in Perinatal Medicine. Fetal Diagn Ther. 2004;19:366-9.

47. Rosenfeld CS. Sex-Specific Placental Responses in Fetal Development. Endocrinology. 2015;156:3422-34.

48. Osei-Kumah A, Smith R, Jurisica I, Caniggia I, Clifton VL. Sex-specific differences in placental global gene expression in pregnancies complicated by asthma. Placenta. 2011;32:570-8.

Submit your next manuscript to BioMed Central and we will help you at every step:

- We accept pre-submission inquiries

- Our selector tool helps you to find the most relevant journal

- We provide round the clock customer support

- Convenient online submission

- Thorough peer review

- Inclusion in PubMed and all major indexing services

- Maximum visibility for your research

Submit your manuscript at www.biomedcentral.com/submit
Biomed Central 